Faculty of Humanities

Faculty Publications

Indigenous Storytelling, Truth-telling, and Community Approaches to Reconciliation

Corntassel, J., Chaw-win-is, \& T'lakwadzi.

2009.

(C) 2009 Corntassel, J., Chaw-win-is, \& T'lakwadzi.

This article was originally published at:

https://ojs.lib.uwo.ca/index.php/esc/article/view/9788/7888

Citation for this paper:

Corntassel, J., Chaw-win-is, \& T'lakwadzi. (2009). Indigenous Storytelling, Truthtelling, and Community Approaches to Reconciliation. ESC: English Studies in Canada, 35(1). https://ojs.lib.uwo.ca/index. php/esc/article/view/9788/7888 


\title{
Indigenous Storytelling, Truth-telling, and Community Approaches to Reconciliation
}

\author{
Jeff Corntassel \\ Chaw-win-is \\ T'lakwadzi \\ University of Victoria
}

$\mathbf{I}$

NDIGENOUS STORYTELLING IS CONNECTED TO OUR HOMELANDS and is crucial to the cultural and political resurgence of Indigenous nations. According to Maori scholar Linda Smith, “'The talk' about the colonial past is embedded in our political discourses, our humour, poetry, music, storytelling, and other common sense ways of passing on both a narrative of history and an attitude about history" (19). For example, when conveying community narratives of history to future generations, Nuu-chah-nulth peoples have relied on haa-huu-pah as teaching stories or sacred living histories that solidify ancestral and contemporary connections to place. ${ }^{1}$ As Nuu-chah-nulth Elder Cha-chin-sun-up states, haa-huu-pah are "What we do when we get up every day to make the world good." Haa-huu-pah

1 The Nuu-chah-nulth word haa-huu-pah is plural in its usage. Also, the ha'houlthee (chiefly territories) of the Nuu-chah-nulth peoples cover approximately three hundred kilometres of the Pacific Coast of Vancouver Island, from Brooks Peninsula in the north to Point-no-Point in the south, and includes inland regions. The fourteen Nuu-chah-nulth First Nations are divided into three regions: Southern Region: Ditidaht, Huu-ay-aht, Hupacasath, Tse-shaht, and Uchucklesaht; Central Region: Ahousaht, Hesquiaht, Tla-o-qui-aht, Toquaht, and Ucluelet; and Northern Region: Ehattesaht, Kyuquot/Cheklesahht, Mowachat/Muchalaht, and Nuchatlaht.

ESC 35.1 (March 2009): 137-159 
JefF CoRntassel

(Cherokee Nation) is

an Associate Professor and Graduate Advisor

in the Indigenous

Governance Program

at the University of

Victoria. His research and teaching interests

include Indigenous political mobilization/

self-determination movements and community-

based approaches to truth-telling.

Forced Federalism:

Contemporary

Challenges to Indigenous

Nationhood (2008, University of Oklahoma Press), examines how

Indigenous nations

in the U.S. have

mobilized politically

as they encounter

new threats to their governance from state policymakers. He has also been published in Alternatives, American

Indian Quarterly,

Global Governance, Human Rights Quarterly, Nationalism and Ethnic Studies, and Social Science Journal. are not fairy tales or entertaining stories for children-they are lived values that form the basis for Indigenous governance and regeneration. The experiential knowledge and living histories of haa-huu-pah comprise part of the core teachings that Indigenous families transmit to future generations.

The nation-state of Canada offers a very different version of history than those of Indigenous nations-one that glosses over the colonial legacies of removing Indigenous peoples from their families and homelands when enforcing assimilationist policies, all of which were intended to eradicate Indigenous nations. The residential school era, which can be said to begin in 1874, is one example of the racist policies that were imposed on Indigenous people. ${ }^{2}$ Designed to strip Indigenous people of their languages and cultures, the residential schools were administered by the government of Canada and run by four well-known denominations or churches. By the time the last residential school closed in 1996, over one-hundred-thousand Indigenous children had been forcibly removed from their homes. ${ }^{3}$

According to Paulette Regan, Euro-Canadian scholar and academic liaison to Truth and Reconciliation Canada (TRC), settler Canadians have much to account for:

Settler violence against Indigenous peoples is woven into the fabric of Canadian history in an unbroken thread from past to present that we must now unravel, unsettling our comfortable assumptions about the past. At the same time, we must work as Indigenous allies to "restory" the dominant culture version of history; that is, we must make decolonizing space for Indigenous history-counter-narratives of diplomacy, law, and peacemaking practices-as told by Indigenous peoples themselves. (2)

Given the monumental task ahead to restory the settler version of history, this paper explores the structure of Truth and Reconciliation Canada along with some of the criticisms that have emerged recently from residential school survivors regarding the shortcomings of Canada's attempts at reparations for residential school survivors in the form of Common

2 Bradford Morse provides 1874 as the date from which "[T]he Canadian government began to play a role in the development and administration of the Indian residential school system" (280).

3 See Roland Chrisjohn and Sherri Young with Michael Maraun, The Circle Game (1997). For an in-depth look at the history of Indian residential schools as well as truth and reconciliation processes in Canada, see the two-volume edited series published by the Aboriginal Healing Foundation, From Truth to Reconciliation (2009) and Response, Responsibility (2008).

138 Corntassel, Chaw-win-is, and T'lakwadzi 
Experience Payments (CEP). We anchor our discussion in haa-huu-pah as a form of truth-telling in order to demonstrate how Indigenous stories of resilience are critical to the resurgence of our communities. Moreover, haa-huu-pah are fundamental to teaching our families and communities who we are and how to govern ourselves on this land, intending to lead us toward action. After all, "Awareness of truth [...] compels some kind of action" (Waziyatawin 11). Processes of restorying and truth-telling are not effective without some larger community-centred, decolonizing actions behind them.

Thus, haa-huu-pah signify a starting point for renewing Indigenous family and community responsibilities in the ongoing struggle for Indigenous justice and freedom. Haa-huu-pah also represent an alternative to the Canadian state's vision for reconciliation, which seeks to legitimize the status quo rather than to rectify injustice for Indigenous communities.

As Taiaiake Alfred and Jeff Corntassel point out, "[T]here is a danger in allowing colonization to be the only story of Indigenous lives. It must be recognized that colonialism is a narrative in which the Settler's power is the fundamental reference and assumption, inherently limiting Indigenous freedom and imposing a view of the world that is but an outcome or perspective on that power" (601). A restorying process for Indigenous peoples entails questioning the imposition of colonial histories on our communities. The origin of the name Canada provides some clues regarding the scope of injustices that need to be rectified before restitution and reconciliation can actually be achieved. Alfred, a Kanien'kehaka (Mohawk) scholar, reminds us that the word Canada is derived from a Kanien'kehaka term, Kanatiens, which means "They sit in our village." A contemporary translation of this term would be "squatter." Given the origins of Canada, what can descendants of squatters or settlers offer Indigenous peoples by way of reconciliation? Where does one start in terms of reconciling Canada?

This research project on restorying Indigenous justice started shortly after Cherokee Nation scholar Jeff Corntassel participated in a 2008 TRC conference in Montreal, focusing on the TRC's potential for truth-telling and public engagement as it began its five-year mandate. Questions posed by Lyackson First Nation scholar Qwul'sih'yah'maht were especially thought-provoking: What will the TRC do with the survivors' stories? And how will the resilience and power of these stories be represented in the testimony? After reflecting on the colonial legacy of boarding schools in the U.S. and their detrimental impacts on Indigenous nations, Corntassel saw the need for intergenerational survivors in Canada to speak with
CHAW-WIN-IS

(NUU-CHAH-NULTH) is a doctoral student in the Department of English at the University of Victoria. She received her Master of Arts at the University of Victoria's Indigenous Governance Program in 2007. Her research interests include Indigenous storytelling and governance with an emphasis on regenerating Indigenouscentred approaches to research. Chaw-win-is's work on decolonizing gender roles and Indigenous storytelling will be published in two forthcoming edited volumes: For Indigenous Eyes Only (Michael Yellowbird and Waziyatawin, eds., 2011) and The Power of Peoplehood (Jeff Corntassel and Tom Holm, eds., 2010). 
T'LAKWADZI (Gary

Dawson-Quatell, Kwakwaka'wakw) is a former LE,NONET research apprentice, which led to this research collaboration on residential school survivors based on the interviews T'lakwadzi conducted in summer 2009. T'lakwadzi is also a former Firekeeper for the Native Student Union at the University of Victoria. T'lakwadzi is currently working towards a Bachelor of Social Work Degree at the University of

Victoria. each other within a community context and learn from other survivors' stories of resistance and resilience. Around this time, T'lakwadzi, a Kwakwaka'wakw student, approached Corntassel about serving as a faculty mentor on reconciliation via the University of Victoria's LE,NONET research apprentice program. ${ }^{4}$ As T'lakwadzi and Corntassel set up a research project that entailed interviewing Indian residential school survivors, they realized that by emphasizing the cultural and spiritual dimensions of survivors' experiences this research could serve as an alternative to the political/legal constraints of the TRC process.

During the summer of 2009, T'lakwadzi conducted seven in-depth interviews with residential school survivors and encouraged each participant to focus on the community, family, and individual impacts of residential school on their lives rather than framing the discussion around Indigenous reconciliation with Canada. Nuu-chah-nulth doctoral student Chaw-win-is was asked to join this project after the interviews had been completed in order to provide some insights into Nuu-chah-nulth perspectives on survivor truth-telling and to draw on her expertise in haa-huh-pah. This collaboration of Indigenous scholars and survivors from different nations and generations offers unique insights into community notions of truth-telling and justice.

Overall, while the Indian Residential School Settlement Agreement and the formation of the TRC are designed to address the devastating legacies of residential schools, they run the risk of framing these questions in a narrow way that neglects to fully appreciate the ongoing impacts of residential schools on communities, families, and individuals and the lived experiences of resilience and resurgence that need to be shared with intergenerational survivors and other Indigenous peoples. State-centred processes of reconciliation attempt to repair the damages caused by residential schools but do little to reunify and regenerate families and communities dispersed and dislocated by the trauma of these schools. As Nuu-chah-nulth Elder Barney Williams Jr, explains, “Our Nuu-chah-nulth methodologies are missing from the TRC-our ways like many other Native

4. The Kwakwaka'wakw (formerly known as the Kwakiutl) are an Indigenous group of First Nations living in northern Vancouver Island, as well as the adjoining mainland and islands of British Columbia, and number approximately fifty-five hundred people.

LE,NONET is a SENCOTEN (Straits Salish) word meaning "success after enduring many hardships." The LE,NONET Project (2004-2009) was designed to help facilitate opportunities for students for community internships, peer mentoring, and research apprenticeships with faculty members at the University of Victoria.

140 | Corntassel, Chaw-win-is, and T'lakwadzi 
peoples' ways, have sustained us for centuries and will continue to do so if we continue to use them in our families and communities."

In this paper we focus on Indigenous methodologies and experiential knowledge as a counter-narrative to the Canadian state's notion of reconciliation. The section that follows lays out the structure and mandate of the TRC along with theoretical and applied approaches to the concept of reconciliation. A subsequent section on restorying justice focuses on the methodology and the findings from the seven interviews conducted by T'lakwadzi. Drawing on the Quu'asa family way and storytelling methodologies, we view these interviews as living histories and truths that need to be conveyed to future generations so that movements toward decolonization and justice can be realized. Additionally, the seven interviews serve as a counter-narrative to the political/legal testimonies of the TRC and are contemporary versions of haa-huu-pah as well as community-centred visions for resurgence and renewal.

\section{The Apparatus of Official Reconciliation in Canada}

Websites relating to the "Indian Residential School Settlement Agreement" epitomize some of the confusion over the notion of reconciliation in Canada. One such website has a photograph of what appears to be a Yonega or Maamaathni (word for white settler in Cherokee or "boat people that have no land and live on the ocean" in Nuu-chah-nulth) arm outstretched and cupping a small eagle feather. The caption states "The healing continues." Just what is the message being conveyed here? Is it that the dominant society is either giving something back to Indigenous peoples or holding something for us? More importantly, where are the Indigenous peoples in this picture? Are they willing to receive what is being offered? And by what authority does the Government of Canada, as a colonial entity illegally occupying Indigenous homelands, make such an offer of redress?

Truth and Reconciliation Canada was formed on 1 June 2008 to address the genocidal legacy of residential schools resulting in the forced removal of Indigenous children from their families and homelands. The TRC is the cornerstone of the May 2006 Indian Residential School Agreement, ${ }^{5}$ which was in "response to numerous class action claims involving over 12,000 5 See 2007 Indian Residential Schools Settlement Agreement www.iap-pei.ca/ content/pdf/irssa-settlement.pdf. As part of the Indian Residential Schools Settlement Agreement, financial compensation in the form of a Common Experience Payment (CEP) is to be awarded to residential school survivors once they verify their attendance at these schools. According to the settlement agreement, the amount of the CEP is determined by the following criteria: 
individual litigants" (Morse 283) and signed by the Government of Canada, the Assembly of First Nations, regional Inuit representatives, representatives of the four churches who once administered the residential schools, and the several lawyers involved in the negotiation process. While the TRC was sidelined for over a year due to the resignations of the former chair and commissioners, three new commissioners were appointed in June 2009, and the TRC has begun to pursue its mandate once again by undertaking a truth and reconciliation process with Indigenous survivors, which will include educating the general public about residential schools and producing a comprehensive report along with recommendations based on their findings at the conclusion of the five-year mandate. This is the first TRC to ever focus exclusively on crimes committed against Indigenous children, and it has a five-year time frame in which to undertake its mission.

Despite the comprehensiveness of the Indian Residential Schools Settlement Agreement, a question that we posed at the beginning of this section still lingers: Where are the Indigenous peoples in this picture? One response came in November 2008 when Indigenous Elders from the Indian Residential School Survivors Society (IRSSS) gathered in Calgary to lay out their perspectives on the TRC and issue an official statement to the government of Canada. ${ }^{6}$ Here are three of their main points:

- Today we gathered because of our children and grandchildren [...] You are the keepers of who we are. To Canadians we say: Take responsibility for educating yourself and your children.

(1) ten thousand dollars (\$10,0oo.oo) to every Eligible CEP Recipient who resided at one or more Indian Residential Schools for one school year or part thereof; and

(2) an additional three thousand $(\$ 3,000.00)$ to every eligible CEP Recipient who resided at one or more Indian Residential Schools for each school year or part thereof, after the first school year; and

(3) less the amount of any advance payment on the CEP received.

In addition to the CEP, an Independent Assessment Process (IAP) allows survivors who suffered sexual, physical, or other abuses to apply to receive from $\$ 5$, ooo to $\$ 275$, ooo in compensation from the Canadian government. To be eligible for IAP payments, survivors must demonstrate harm in terms of serious psychological impairment and even loss of income.

6 The IRSSS was created in 1994 as a working committee of the First Nations Summit and currently represents approximately 70 percent of all Indigenous peoples in British Columbia. www.irsss.ca/about_us.html. 
- The TRC has to address the need for ongoing healing. Once the stories start to flow we will have embarked on a journey across a tidal wave of pain. Care is being provided for persons preparing to offer their truth to the commission and we would ask that spiritual support be available for people after they have presented.

- The TRC needs to recognize where all survivors, families, communities, and nations are in terms of readiness for reconciliation. We must go slowly. We cannot force reconciliation.

The IRSSS statements highlight the need for a community-based impetus to move beyond the TRC mandate toward restorying at the family and community levels. Additionally, there is a call for youth and other intergenerational survivors to be involved in the process. Furthermore, spiritual support, not just monetary support, is crucial for all people involved in the process. These recommendations might be implemented in a number of ways. The 2009 community-led demolition of Peake Hall Residential School in Port Alberni, British Columbia, offers insight into one community-centred event emphasizing the connection between truth-telling and acting to restore justice.

On 10 February 2009, the demolition of a former residential school building took place on the territory of Tseshaht First Nation. Peake Hall had originally opened its doors in 1920 and was closed by 1972. During its fifty-two-year operation, Peake Hall was regarded as one of the worst Canadian residential schools in terms of the violence it imposed on Indigenous children: its operations produced "stories whose basis still keeps survivors awake at night, in fear, shame and dread" (ciquiut 1). The Tseshaht Nation hosted a ceremony for all survivors and their families (including other Indigenous communities impacted by the violence of Peake Hall) and started by holding a pre-demolition day at Peake Hall, "using traditional and cultural methods to take the power away from the school once and for all" (ciquiut 2). Crowbars and sledgehammers were also provided to anyone who wanted to pry off pieces of the building for a burning. Throughout the day, two fires were kept going so that survivors could burn "pieces of the discarded siding from the building" (ciquiut 8). Sage and cedar were also burned with the pieces, in order to "cleanse and allow the trapped spirits to be finally freed" (ciquiut 8). Ray Guno, a sixty-four-year-old Nisga'a from Terrace, reflected on the demolition ceremony: "Ten guys I know, some of them my closest buddies, died in the 50s. Not from natural causes, but from sexual, emotional and physical abuses. Not to have come down [to tear apart the old school] would have 
cheapened their lives and their experiences" (Winks). After the demolition, families came together for a community feast in Maht Mahs. With over two hundred places set, there was only standing room available. According to Tseshaht Elder, Willard Gallic, who led the ceremony, "I feel very comfortable that what was set out was accomplished. Listening to the survivors helped us to help them" (ciquiut 8). This event is just one example of restorying and resurgence occurring within Indigenous communities as a way to counter the ongoing colonial legacies of residential schools. The community demolition of Peake Hall demonstrates the kind of political and spiritual or healing work that is needed in order to begin working toward restitution. Indigenous peoples acting together in this way by linking political action and cultural teachings begin to draw the focus back to community and family processes of restorying justice and history, as a means to challenge the colonial relationship with Canada.

According to the preamble for the TRC mandate, "There is an emerging and compelling desire to put the events of the past behind us so that we can work towards a stronger and healthier future[...]. The truth of our common experiences will help set our spirits free and pave the way to reconciliation" (Mandate of the Truth and Reconciliation Commission). The stated desire to "put events of the past behind us" and unite a deeply divided society expresses the underlying logic of most truth commissions, which view reconciliation processes in terms of a "preparedness of people to anticipate a shared future" through forgiveness but also shared strategies for moving forward collectively to repair existing relationships (Rigby 12). However, as anthropologist Stephanie Irlbacher-Fox points out, "The result is that, by conflating specific unjust events, policies, and laws with 'history', what is unjust becomes temporally separate from the present, unchangeable. This narrows options for restitution: we cannot change the past" (33). Such a convenient framing of the issue allows political leaders and settler populations to deal with residual guilt on their own terms, which often follows all too familiar scripts of "forgiving and forgetting," "moving on from the past," and "unifying as a country," all the while brushing aside any deeper discussions of restitution or justice. Reconciliation becomes a way for the dominant culture to reinscribe the status quo rather than to make amends for previous injustices.

According to Alfred, "The logic of reconciliation as justice is clear: without massive restitution, including land, financial transfers and other forms of assistance to compensate for past harms and continuing injustices committed against our peoples, reconciliation would permanently enshrine colonial injustices and is itself a further injustice" (152). Any

144 | Corntassel, Chaw-win-is, and T'lakwadzi 
meaningful reconciliation effort must confront colonialism not only historically but as part of an ongoing process that continues to impact present generations of Indigenous youth and families. It is an uncomfortable process, but, as scholars have noted, regardless of which truth-seeking strategy is chosen, one must come to terms with "the unavoidable tensions, the lack of tidiness involved in any response to large scale evil" (Verwoerd 265). As philosopher Claudia Card states, "Sometimes it is wise to reconcile only conditionally on the offender's living up to obligations of reparation or restitution" (179).

Not only do state applications of reconciliation tend to relegate all committed injustices to the past while attempting to legitimate the status quo but there is another underlying motive at play: certainty. As anthropologist Paul Nadasdy points out, "Without certainty of title, there is always the danger that a corporation might lose its investment as the result of a lawsuit brought against it by aboriginal people" (86). Given an overarching desire to secure a stable land base to facilitate corporate investment, the Government of Canada, as well as certain provinces, including British Columbia, have begun to use the language of reconciliation in negotiations with Indigenous peoples (for example, in the B.C. Treaty Process as well as in the proposed "New Relationship" legislation) in order to establish the "certainty" of a land claim in such a way as to facilitate the extinguishment of original Indigenous title to the land. ${ }^{7}$ When state objectives, such as certainty and legitimation, tend to override questions of justice, it becomes clear that any pursuit of reconciliation with the state must first acknowledge the asymmetrical power relationships between states and Indigenous peoples which can so easily derail questions of justice and decolonization.

At its core, reconciliation is a Western concept with religious connotations of restoring one's relationship to God. Given that reconciliation is not an Indigenous concept, our overarching goal as Indigenous peoples should not be to restore an asymmetrical relationship with the state but to restory our communities toward justice.

There is no word for reconciliation in Nuu-chah-nulth. The Nuu-chahnulth word oo yoothloothl, "looking after (or, looking beyond)," exemplifies a commitment to move forward or beyond the problem. According to Nuu-chah-nulth Elder, Barney Williams Jr, when communities need to deal with challenges, the process begins with family. Hishimyoothoothl,

7 See, for example, research by Carole Blackburn and Andrew Woolford on this topic. 
The issue of

land is treated

as a separate

issue from that

of the residential

school, ignor-

ing the fact that

the issues with

which survivors

from the resi-

dential school

era contend are

rooted in the

forced removal

of entire families

and communi-

ties from their

homelands. means "to gather our family." This means the family will meet to discuss the problem and together they will strategize how best to deal with the situation. There may be several meetings with families before they reach out to the broader Nuu-chah-nulth communities. For Nuu-chah-nulth, this next step may mean planning a larger gathering called nuushitl or maathmaya where we call on other communities to both witness and rectify the situation. Working within the familial system is especially adhered to when dealing with children and child-rearing practices. At the closing of these feasts or gatherings, the Nuu-chah-nulth will often say the words yoots pah nah ahts mish or "We will be careful as we go." This is said with love and care as relatives leave to travel back to their homes, reminding everyone of our responsibility to travel home safely and for each of us to live every day in iisaak, in a respectful way.

Processes of renewing community responsibilities through feasts or gatherings are not necessarily available in the TRC structure. Additionally, rather than use the state-centred language of reconciliation, our focus is on family-centred, community resurgence, and restorying justice. In the section that follows, we discuss some of the findings from our interviews of seven residential school survivors from Nuu-chah-nulth and Kwakwaka'wakw First Nations.

\section{Restorying Beyond the TRC Mandate}

Legal scholar Teresa Godwin Phelps has outlined the ways in which truth commissions can provide justice through storytelling, among them, the restoration of dignity and "the ability to speak in one's own voice," the "correction" of false stories, the communication of the "experience of pain and suffering between people who normally cannot understand each other" and the occasioning of forms of remembering which can heal and even "actualize a radically new kind of constitutive history for an emerging democracy" (55-56).

While Phelps's list includes some important aspects of storytelling, the emphasis is still largely on forgiveness and unifying societies in relation to the state. Furthermore, there is no reference here to the issue of Indigenous peoples and land. The TRC was designed to fit within a Western model of justice where individuals may seek compensation (usually financial) for their losses. The issue of land is treated as a separate issue from that of the residential school, ignoring the fact that the issues with which survivors from the residential school era contend are rooted in the forced removal of entire families and communities from their homelands.

146 | Corntassel, Chaw-win-is, and T'lakwadzi 
Lyackson scholar Qwul'sih'yah'maht (Robina Thomas) outlines a storytelling methodology that is useful for our purposes: "Delmar Johnnie once said that it is such a shame that every time someone who went to residential school dies without telling his or her stories, our government and the churches look more innocent. Telling these stories is a form of resistance to colonization.[...] I believe that storytelling respects and honours people while simultaneously documenting their reality" (241-42, 244). As Qwul'sih'yah'maht's words indicate, restorying can facilitate both truth-telling and acts of resistance. It can also expose some blind spots in Phelps's discourse on storytelling, namely that Indigenous restorying processes cannot be disentangled from ongoing relationships to their homelands.

Elaborating on a storytelling methodology, Chaw-win-is uses a "Quu'asa family way," which is an Indigenous-centred methodology presently used within Nuu-chah-nulth communities as a way of regenerating haa-huu-pah through relational accountability and truth-telling. This Quu'asa family way views haa-huu-pah as a layer of community governance and leadership that emphasizes the renewal of Indigenous roles and responsibilities to the land and community. Using a Quu'asa family way storytelling methodology allows us to draw linkages between themes of land, family, living histories, and acts of resistance, while offering an alternative narrative to state-centred reconciliation presented by the TRC.

In the summer of 2009, T'lakwadzi (Kwakwaka'wakw) conducted interviews with seven male residential school survivors in Nuu-chahnulth and Kwakwaka'wakw communities. ${ }^{8}$ While there are always risks in discussing the traumatic experiences that occurred in residential schools, we tried to reduce the risk by providing free access to culturally-relevant

8 While we originally planned to interview several female residential school survivors, the following seven men were the only ones available for interviews during our time frame: Kwi-ahts-ah-pulth (Jack Little) from Ahousaht First Nation (Nuu-chah-nulth); Hayawolthlit (Wally Samuel Sr) from Ahousaht First Nation (Nuu-chah-nulth); Luke George from Tseshaht First Nation (Nuu-chah-nulth); Huu-ay-aht (Stephen Lucas) from Hesquiaht First Nation (Nuu-chah-nulth); James Quatell from Wei-wai-kum First Nation (Kwakwaka'wakw); Daniel Wallace Quatell from Wei-wai-kum First Nation (Kwakwaka'wakw); and Heyawaladzi (Camble Mark Quatell) from Wei-wai-kum First Nation (Kwakwaka'wakw).

The amount of time these survivors spent in residential school ranged from one to ten years. In keeping with community protocols, we provided a gift to each participant in order to honour the knowledge and time shared with us. As part of the University of Victoria's research ethics requirements, each participant signed a consent form, which stated that if he chose to withdraw from the study at any time and for any reason, his interview data would be destroyed and not used in the analysis. None of the participants chose this option. 
counseling options for each participant along with frequent follow-up phone calls by T'lakwadzi. T'lakwadzi's follow-ups with the participants also allowed each person to double-check the transcripts and express any reservations about wanting his stories told. All of the participants emphatically stated said that they wanted their stories told and stressed in different ways that there was no room within the current TRC process for a community perspective to be really heard.

Using a Quu'asa family way storytelling methodology, we identified four main themes that each participant addresses to varying degrees: homeland, family, restitution, and restorying. These concepts were all interrelated and offered some insights into how community-based restorying differs from state-based reconciliation efforts.

\section{Homeland}

When asked whether land should be a part of a reconciliation process, Hayawolthlit (Wally Samuel Sr) from Ahousaht First Nation expressed concerns that the reconciliation process was ignoring the fact that most survivors were currently living outside their home territory (often in urban areas): "What would make it genuine if they were actually doing this, talking to the individuals. And not to the nations, because 80 percent of us live away from home. Especially residential school people and their families are all away from home."

James Quatell (Wei-wai-kum First Nation) went even further by pointing out that the reconciliation process purposefully excluded land from the discussion:

T'lakwadzi What about land, do you think land will and should be part of the TRC?

JQ Not sure that anything can be done because that subject falls under the treaty aspects. It is not that I don't think it should be a part of it all but they have gone and capped it. They have capped it under the one word-reconciliation.

T'lakwadzi But do you think it should be a part of the process?

JQ It should be the biggest part of all because all the people were taken from their land and resources and they would have had that if they were not taken from their communities and villages. We weren't educated to do this. We weren't educated 
to get all these resources, the education of it was never going

to be there. So how can I say that never affected it, it did!

Dan Quatell (Wei-wai-kum First Nation) also described the importance of homeland to his family and community and how these relationships have been disrupted:

T'lakwadzi Moving on to the next question, which is about land, should land be part of the TRC?

DQ Definitely, look at what the government is doing to our lands, look how big we are and look at how small our land is becoming. We're fighting for our land, I can remember my grandfather having two or three big houses down at the spit and now we're fighting for that land. The land where Save On is, it was and is band land. But they say we have to go to court for now, but we allowed the Old Elm school and the church to go on our land and now they are saying it is not our land.

As the above responses indicate, for Indigenous peoples, our homelands are our future and cannot be separated from our grounding in community, languages, living histories, and ceremonial lives. These interconnected relationships all form the foundation for effective resistance to contemporary colonialism.

\section{Family}

When asked about the impacts of residential schools on intergenerational survivors, Kwi-ahts-ah-pulth from Ahousaht First Nation spoke bluntly about the importance of family members in the reconciliation process:

T'lakwadzi What about family members, first- and second-generation family members that didn't go to residential schools; just wondering how you think they can be included in the equation or if they should be included in the equation at all?

K That is a tough one because there is still effects with our siblings, with our children, with our nephews, nieces, our grandchildren-there is still effects. But I can still see possible, possibility they could be. Playing devil's advocate thinking from the perspective of the government that would have to pay there is no way that they would, and I understand that, I understand why. But in lieu of that maybe what the government can be doing to support the families that want to heal themselves, those of a first, second, and third generation and 


\section{"Not only hear}

\section{their stories but}

\section{find solutions;}

how can we

help this person,

how can we

help the com-

munity? How

can we help this

family? What is

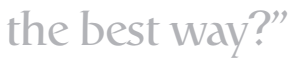

the generations of children and grandchildren that have gone to residential schools, that some programs should be made available for them to understand the impacts of what residential schools did to their siblings, their parents, to their aunts, uncles, and grandparents. Get a firmer understanding of what transpired and what happened, that is one way of parties possibly working together for that benefit.

T'lakwadzi If you had any suggestions for the process, what would they be? Or if you could frame the TRC the way you would like it to be how would that look?

K Make it real, I would want the committee to listen to everyone's story, that every life, every person, that it is important to hear everyone's story. Not only hear their stories but find solutions; how can we help this person, how can we help the community? How can we help this family? What is the best way? This band is in so much debt and this chief has a lot of wealth. So we have adapted very well to that European concept and business concept of money. In my opinion we need to get back to our grass roots and our traditions and cultures and the wealth of a person and the wealth of a community is family, is the culture, is the traditional teachings. It is the land, the sea, the resources-that is what we talk about when we say how "rich" a chief is! Because a chief can be very rich if he has access or practices his access to the resources in his territory. There is an abundance of it! The wealth is our culture, it is our naming ceremonies, our potlatches, our wedding ceremonies, our memorial potlatches, it is our masks, it is all the wonders of art that come from an artist who has great teachings and knowledge of practice of what mother nature has given us. To me that is more real, and we need to get back to those ways and those kinds of teachings is the ways we are going to be able to move forward as a person, as a family, as a community.

Hayawolthlit (Ahousaht First Nation) spoke of how residential school traumas were being passed down through the generations and the need to address this reality within community:

$\mathrm{H}$ They should offer programs that include all family members. Again I'd like to see more local planned programs for families. A lot of us don't realize [what] our attitudes are, that we do it to our own kids. Stand up, straight, sit down, all those stringent

150 | Corntassel, Chaw-win-is, and T'lakwadzi 
rules we had, we can't go on until the dishes are washed, but this is normal.

Even since the last federally funded residential school closed in 1996, Indigenous families have continued to be under attack by government agencies, such as the Ministry of Children and Family Development. In fact, there are more Indigenous children in government care today than at the height of residential schools (Matas). Despite comprising only 4.4 percent of the overall population in British Columbia, Indigenous children make up a staggering 52 per cent of children in government care (Matas). Furthermore, Indigenous children are 6.3 times more likely to be admitted into care and, once accepted into care, 12.4 times more likely to remain in care (Matas). These statistics offer a sobering view of the current state of reconciliation in Canada involving Indigenous families, who continue to struggle against the contemporary manifestations of colonialism in Canada.

\section{Restitution}

A common theme in the interviews around issues of compensation for years spent in residential school through the Common Experience Payments (CEP) was one of representation. James Quatell (Wei-wai-kum First Nation) described what he witnessed at the consultation meetings:

Mr. Fontaine's answer to one of the elders from the Squamish Nation [who asked], where did you get such a ludicrous figure that you're taking this to the Supreme Court? His answer: was Oh no, no, no, this is not written in stone. This is just for him to take there and negotiate on your behalf. It was $\$ 10,000$ for finding out you were there for the first year and $\$ 3$, ooo for every year after that. The retired Supreme Court judge was going in and they told us the decision would not be made until around March of the following year; however, a decision was made in November of that same year. Which was way before the said time. Guess what, it was ten and three. My question to Mr Fontaine was because I never was consulted I can take you to court for misrepresentation.

Another theme in the interviews was the inadequacy of the CEP amount. After all, in 1989, after investigations demonstrated that priests physically and sexually abused white minors at the Mount Cashel Orphanage in St John's, Newfoundland, between 1951 and 1960, the compensation being offered to the victims was significant (Burns). Between 1996 and 2004, \$27 million was paid by the Newfoundland government and the 
Christian Brothers in compensation to approximately eighty-five Mount Cashel victims ( $C B C$ News). This is roughly $\$ 270$, ooo for each victim of residential school abuse, which is far more than the current CEP being offered to Indigenous survivors.

When asked if he received the CEP monies, Hayawolthlit (Ahousaht First Nation) stated: "Yes, but it did not make life any better ... [Lots of laughter]. The sad part is we missed out on a lot of cultural aspects, we were put in a mixed environment, we couldn't speak our languages, we all had to speak English. I got some of the money but not enough" [Laughs again].

Luke George (Tseshaht First Nation) elaborates on the points that the CEP money does not begin to account for cultural loss:

Even with that money it still didn't make me feel better. [If] the government really want to reconcile with us they would make funding for language more accessible. I cannot leave my job to go and focus on learning the language because I need to make a living. Maybe take a certain time off each year so we can learn a language. Something bigger and more real than just talk, because it is just talk all the time.

Survivors also reflected on the impacts that the CEP monetary payout had on the individuals, families, and communities receiving the money. Due to some deep misunderstandings regarding the extent of "historical unresolved trauma" within Indigenous communities as well as "ongoing multigenerational processes of dispossession and oppression," the CEP process runs the risk of exacerbating these unresolved personal and community traumas given that it does not address the roots of Indigenous survivor suffering (Alfred 19). While adequate restitution cannot be denied to Indigenous peoples simply because of historically unresolved trauma, it points to the need for deeper community-centred processes, such as the burning of Peake Hall, to facilitate healing and renewal among families and individuals. The following survivor testimonies regarding the impact of the CEP must be examined within a broader context of ongoing colonialism, unresolved historical trauma, and the systematic disruption of their traditional sources of strength: community, homeland, language, ceremonial life, sacred living histories, etc. In 2008, the Indian Residential Schools Survival Society (IRsss) sent out surveys to Indigenous communities in British Columbia and found that "An increase in alcohol use has been recorded especially in the North; an increase in depression and suicide rates in the interior region" ("Residential School Cash"). According 
to IRsss worker Brenda Reynolds, "In B.C., as far as we know, there are 24 deaths that different communities attribute to the common experience payment" ("Residential School Cash"). Overall, CEPs to Indian residential school survivors have led to suicides, substance abuse, and depression across Canada. Kwi-ahts-ah-pulth (Ahousaht First Nation) remembered his response to receiving the CEP:

Looking back at that day I can remember pulling off to the side of the road ... just being a mess ... very mixed emotions and had a good cry and phoned my wife up and told her what was going on, there is no sense of satisfaction, there is no sense of gratification. It is a small amount of payment for what a survivor or any survivor had to go through. We as Kuu'us, as Nuu-chah-nulth, we always say we value life, that life is precious. It makes you think is my life only worth $\$ 3,000$ dollars a year; after the first year your life is worth $\$ 10,000$, after the second year your life is worth $\$ 13,000,3$ years you're worth $\$ 16,000$ and on and on and on. It's miniscule to the amount of pain and suffering that generations and generations and generations of people had to go through from [...] the late 1800 's right to 1983 .

\section{Restorying}

When addressing the G20 in Pittsburgh, Pennsylvania, on 25 September 2009, Canadian Prime Minister Stephen Harper made the infamous statement that "we" in Canada "have no history of colonialism" (Ljunggren). Interestingly, Prime Minister Harper's statement comes less than a year after he offered an apology to Indigenous peoples in Canada for the colonial policy of residential school. Such a clear contradiction only heightens the need for Indigenous restorying and resurgence. So we asked seven residential school survivors, what, if given the opportunity, they would tell the government and the public about their residential school experiences. Their answers gave us some insights into the contemporary struggles for restorying Indigenous futures, as they stressed their disappointment with the resolutions offered by the state. Two respondents, Kwi-ahts-ah-pulth (Jack Little) and Heywaladzi (Campbell Mark Quatell), offered particularly insightful comments regarding engaging with the general public on the legacies of residential schools and the overall resilience of these survivors: 
Kwi-ahts-ah-pulth (Jack Little) To the public I would say "listen." Listen to my story, listen to our story. This is reality, this is what happened to me, this is what happened to my siblings, this is what happened to my parents, this is what happened to my grandparents. And I would paint a scenario and let them know how we were treated. My father would get beaten to a pulp by supervisors and he still talks about it and he is almost 74 years old. I would paint the scenarios of when residential schools came. I would want them to be in my shoes if they could. I would explain my story in a skit, and ask for participation; I would appoint certain people to be students of residential school, two people: mother and father; maybe grandparents, the government officials, and I would say I hope it is worth it, and then I would say I am the law, Kuu'us we are the law-natives. You now have to come to our institutions, come to our reserves, you now have to learn Indian, you now have to learn our culture, you now have to learn our religion and how we do things. And guess what, you can't speak English anymore, German, Italian, French - take away their language, take away their custom, and I would paint that scenario and say now the government agent is coming to your home and taking your child away. How would you feel? [...] I am a well respected orator and I will use my skills and [...] then paint some scenarios: here is what happened to me, you are hungry and you didn't eat that day and so you stole from the kitchen. They taught us how to steal. If you got caught, heaven help you if you got caught then you really got punished. So tell my story and give them nothing but facts, and ask them how they feel. So that is what I would do to the public at large.

To the government that is a different story! The governments are hard to deal with. They do not listen to reason so you really can't treat them and talk to them like the public at large-they have feelings, you can reach the people; the government is pawns, they are pawns for their constituents, all they are worried about is the issue of the day. It may be an issue today but tomorrow or next week it is not an issue. The government is a lot harder to deal with but I would let them know that I am very hurt by what happened to myself, my siblings, my family. Honestly ask them if a life is only worth this much? [...] If there were a way of compensation other than money, I think that would be an ultimate medium where you might be able to meet. Money is not going to solve it! I have heard horrendous 
stories of when people got their money. Money is not going to solve it. You can't buy respect, you can't buy love!

Heywaladzi (Campbell Mark Quatell) They are never going to fix what they did to me, because all money and all the tea in China is never going to make that go away.[...] I'm stuck with feeling like a nothing for the rest of my life because that was what I was told from a very early age. [...T] he mental and physical abuse, starvation-how were we supposed to prove all this when most of our correspondence has been blacked out and we only have our word? I asked what if I go way over the maximum amount of points, they said you will not receive any more than the $\$ 275$, ooo. [...] I said you are not taking serious and you have no regard for my story.

Heywaladzi's observations bring our discussion full circle. Ultimately, restorying is just a first step toward remembering and revitalizing our collective and individual consciousness. As Regan points out, these restorying efforts form the basis for "decolonizing spaces" for Indigenous "counternarratives of diplomacy, law, and peacemaking practices." It is within these decolonizing spaces that Indigenous resurgence movements take shape.

\section{From Truth-telling to Community Mobilization}

We have seen how reconciliation as framed by Canada has served to legitimize and reinforce colonial relationships, thus maintaining the status quo. Haa-huu-pah and strategies for Indigenous restorying offer alternatives for resisting contemporary colonial realities and legacies of residential schools. Haa-huu-pah have many layers and are inextricably linked to our homelands and family responsibilities. Throughout the interviews with the seven residential school survivors, there is an acknowledgement that homeland, family, restitution, and restorying are all interconnected. Given that colonialism is ongoing, the renewal of family and community responsibilities are starting points for committing to larger Indigenous movements in pursuit of justice and freedom.

The Nuu-chah-nulth Stop the Violence March (May 2006) is a current example of how haa-huu-pah can be applied to the internalized oppression we experience within communities. The march evolved from political organizing by the women of Tla-o-qui-aht (Tla-o-qui-aht is one of fifteen Nuu-chah-nulth nations). In 2005, a young woman from Tla-o-qui-aht participated in her coming of age ceremony, known as the Ayts tuu thlaa. Tragically, two weeks later this young woman was severely beaten by a man from her own community. The women of Tla-o-qui-aht were out- 
raged and decided to hold a march to demand an end to violence. Fifteen young Nuu-chah-nulth people decided to carry their powerful message throughout all the Nuu-chah-nulth communities. After some wise council from a relative, the participants agreed that their efforts needed to be directed toward countering internalized hatred with yaauukmiss (love) when restoring balance in Nuu-chah-nulth communities through haa-huupah. They did this by bringing a shawl (made and donated by House of Winchee clothing designer, Denise Williams) to each community so they could then choose a young woman who would be "gifted" the shawl. The communities would then each host their own Ayts tuu thlaa ceremony. Ayts tuu thlaa embodies haa-huu-pah regarding respect for all women, as the life-givers of our nations. Further, this ceremony is about a reciprocal commitment between men and women to support the overall well-being of the community. Importantly, in this ceremony, Nuu-chah-nulth people do not look to Canada for solutions. In fact, Nuu-chah-nulth people view state-centred processes as further dividing communities-or trapping us in a cycle of ongoing oppression. In the march, Nuu-chah-nulth people engaged a haa-huu-pah that breathed hope and possibility for the future grounded in our own world-view.

\section{Works Cited}

Aboriginal Healing Foundation. From Truth to Reconciliation: Transforming the Legacy of Residential Schools. Ottawa: Aboriginal Healing Foundation, 2008.

Aboriginal Healing Foundation. Response, Responsibility, and Renewal: Canada's Truth and Reconciliation Journey, Vol. 2. Ottawa: Aboriginal Healing Foundation, 2009.

Alfred, Taiaiake. "Colonialism and State Dependency." National Aboriginal Health Organization. Forthcoming 2010: 1-40.

Alfred, Taiaiake. Wasáse: Indigenous Pathways of Action and Freedom. Ontario: Broadview Press, 2005.

Alfred, Taiaiake. "Indigenous words for leadership." Email to Jeff Corntassel. 28 September 2005.

Alfred, Taiaiake, and Jeff Corntassel. "Being Indigenous: Resurgences against Contemporary Colonialism." Government and Opposition 9 (2005): 597-614.

156 | Corntassel, Chaw-win-is, and T'lakwadzi 
Blackburn, Carole. "Searching for Guarantees in the Midst of Uncertainty: Negotiating Aboriginal Rights and title in British Columbia." American Anthropologist 107 (2005): 586-96.

Burns, John F. “Canadian Prelate Quits In Clerics' Sex Scandal.” The New York Times. 20 July 1990. www.nytimes.com/199\%7/20/world/canadianprelate-quits-in- clerics-sex-scandal.html.

Card, Claudia. The Atrocity Paradigm: A Theory of Evil. Oxford: Oxford UP, 2002.

Cha-chin-sun-up. Personal interview conducted by Chaw-win-is. 10 November 2009.

CBC News. "Compensation for Mount Cashel victims is tangled legal web." 10 November 2003. www.cbc.ca/canada/story/2003/11/10/mtcash elo31110. html.

Chrisjohn, Roland, and Sherri Young with Michael Maraun. The Circle Game: Shadows and Substance in the Indian Residential School Experience in Canada. Penticton: Theytus Books, 1997.

ciquiut: Tseshaht First Nation's Newsletter. "Residential School Finally Offers Some Closure." February 2009: 1-2, 8.

Indian Residential School Survivors Society. "Elders Statement on Truth and Reconciliation Commission." 14. November 2008.www.turtleislan d.org/discussion/viewtopic.php? $\mathrm{p}=9832 \# \mathrm{p} 9832$.

Indian Residential School Survivors Society. "About Us." 10 November 2009.www.irsss.ca/about_us.html.

"Indian Residential Schools Settlement-Official Court Website." 10 November 2009. www.residentialschoolsettlement.ca/English.html.

Irlbacher-Fox, Stephanie. Finding Dahshaa: Self-Government, Social Suffering, and Aboriginal Policy in Canada. Vancouver: University of British Columbia Press, 2009.

“About the LE,NONET Project." 1 March 2010. web.uvic.ca/lenonet/index. html.

Ljunggren, David. "Every G2o nation wants to be Canada, Stephen Harper insists." Calgary Herald. 26 September 2009. www.calgaryherald.com/ business/Every\%2onation\%2owants\%2oCanada\%2oHarper/2037877/ story.html. 
Mandate for the Truth and Reconciliation Commission. Truth and Reconciliation Canada. 11 November 2009. www.trc-cvr.ca/pdfs/ SCHEDULE_N_EN.pdf.

Matas, Robert. "The Numbers Say." Globe and Mail. 19 June 2009. www.theglobeandmail.com/news/national/the-numbers-say/ article1190211.

Morse, Bradford. "Indigenous Peoples of Canada and Their Efforts to Achieve True Reparations." Reparations for Indigenous Peoples: International and Comparative Perspectives. Ed. Federico Lenzerini. Oxford: Oxford UP, 2008. 271-316.

Nadasdy, Paul. "The Antithesis of Restitution? A note on the dynamics of land negotiations in the Yukon, Canada." The Rights and Wrongs of Land Restitution. Eds. Derick Fay and Deborah James. Kentucky: RoutledgeCavendish, 2009. 85-97.

Phelps, Teresa Godwin. Shattered Voices: Language, Violence, and the Work of Truth Commissions. Philadelphia: University of Pennsylvania Press, 2004.

Qwul'sih'yah'maht (Robina Thomas). "Honouring the Oral Traditions of My Ancestors Through Storytelling." Research as Resistance. Eds. Leslie Brown and Susan Strega. Toronto: Canadian Scholars' Press, 2005. 237-54.

Regan, Paulette. Unsettling the Settler Within: Indian Residential Schools, Truth-Telling, and Reconciliation in Canada. Vancouver: University of British Columbia Press, forthcoming 2010.

"Residential school cash has deadly fallout." Calgary Herald. 26 January 2009. www.canada.com/calgaryherald/news/story.html?id=7c2678f1fc12-4eab-bfbf-9f8ob1e49905.

Rigby, Andrew. Justice and Reconciliation: After the Violence. Boulder: Lynne Rienner Publishers, 2001.

Smith, Linda T. Decolonizing Methodologies: Research and Indigenous Peoples. New York: Zed Books, 1999.

Verwoerd, Wilhelm. "Toward a Response to Criticisms of the South Africa Truth and Reconciliation Commission." Dilemmas of Reconciliation: Cases and Concepts. Eds. Carol A.L. Prager and Trudy Govier. Ontario: Wilfrid Laurier UP, 2003. 245-78.

Waziyatawin. What Does Justice Look Like? The Struggle for Liberation in Dakota Homeland. St Paul: Living Justice Press, 2008.

158 | Corntassel, Chaw-win-is, and T'lakwadzi 
Williams, Barney Jr. Personal interview conducted by Chaw-win-is. 10 November 2009.

Winks, Quintin. "Port Alberni residential school destroyed in ceremony." Times Colonist. 11 February 2009. 10 November 2009.

www.timescolonist.com/Port+Alberni+residential+school+destroyed +c eremony/1277833/story.html.

Woolford, Andrew. Between Justice and Certainty: Treaty Making in British Columbia. Vancouver: University of British Columbia Press, 2005. 
